\section{APEM}

\title{
The impact of technical and organisational innovation concepts on product characteristics
}

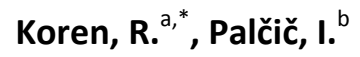 \\ ${ }^{\mathrm{a} P r e m o g o v n i k}$ Velenje, Velenje, Slovenia \\ ${ }^{b}$ University of Maribor, Faculty of mechanical engineering, Maribor, Slovenia
}

\begin{abstract}
A B S T R A C T
The main objective of this paper is to determine the adoption of technologies and organisational concepts in production companies and to analyse how selected technical and organisational concepts affect products' characteristics and their introduction onto the market. A further purpose of this paper is to analyse the impact of technical and organisational concepts on the product complexity and to identify where most impulses for innovation come from, as well as their impact on the product complexity. The results are based on a sample of 89 Slovenian manufacturing companies, the data being obtained through the 2012/13 European Manufacturing Survey edition, providing information on the use and upgrading of the more used technologies and organisational concepts. We found that high usages of technical and organisational concepts have a positive impact on the product characteristics in terms of increasing the proportion of complex products. The results also showed that companies obtained more internal information about new products via sales departments whilst the customers were still the important external source of innovation.
\end{abstract}

\section{ARTICLE INFO}

Keywords:

Innovation

Organisational innovation

Technical innovation

Sources of innovation

Product complexity

*Corresponding author:

rolando.koren@rlv.si

(Koren, R.)

Article history:

Received 17 August 2014

Revised 28 January 2015

Accepted 10 February 2015 


\title{
Vpliv tehničnih in organizacijskih inovacijskih konceptov na značilnosti izdelkov
}

\author{
Koren, R. ${ }^{a,}{ }^{,}$, Palčič, I. ${ }^{b}$

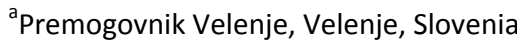 \\ ${ }^{b}$ University of Maribor, Faculty of mechanical engineering, Maribor, Slovenia
}

\section{POVZETEK}

Glavni namen članka je ugotoviti stopnjo rabe tehnologij in organizacijskih konceptov proizvodnih podjetij ter analizirati, kako izbrani tehnični in organizacijski koncepti vplivajo na značilnosti izdelkov ter njihovo uvajanje na trg. Prav tako smo v članku analizirali vpliv tehničnih in organizacijskih konceptov na kompleksnost izdelka ter ugotovili od kod prihaja največ vzgibov za inovacije in njihov vpliv na kompleksnost izdelka. Rezultati, ki temeljijo na vzorcu 89 slovenskih proizvodnih podjetij, katerih podatke smo pridobili s pomočjo anketne raziskave »Raziskava proizvodne dejavnosti v Evropi« (European Manufacturing Survey) iz leta 2012/13, podajajo informacije o uporabi in nadgradnji največkrat uporabljenih tehnologij ter organizacijskih konceptov. Ugotovili smo, da visoka raba tehničnih in organizacijskih konceptov pozitivno vpliva na značilnosti izdelka $\mathrm{v}$ smislu povečanja deleža kompleksnih izdelkov. Rezultati so tudi pokazali, da podjetja dobijo največ internih informacij za nove izdelke s strani prodaje, medtem ko so kupci najpomembnejši zunanji vir.

\section{PODATKI O ČLANKU}

Ključne besede: Inovacije

Organizacijske inovacije

Tehnične inovacije

Viri inovacij

Zapletenost izdelka

*Kontaktna oseba:

rolando.koren@rlv.si

(Koren, R.)

Zgodovina članka:

Prejet 17. avgusta 2014

Popravljen 28. januarja 2015

Sprejet 10. februarja 2015 


\section{References}

[1] McGahan, A. (2004). How industries change, Harvard Business Review, Vol. 82, No. 10, 86-94.

[2] Mumford, M.D. (2000). Managing creative people: Strategies and tactics for innovation, Human Resource Management Review, Vol. 10, No. 3, 313-351, doi: 10.1016/S1053-4822(99)00043-1.

[3] Rigby, D.K., Gruver, K., Allen, J. (2009). Innovation in turbulent times, Harvard Business Review, Vol. 92, No. 6, 7986.

[4] Mol, M.J., Birkinshaw, J. (2009). The sources of management innovation: When firms introduce new management practices, Journal of Business Research, Vol. 62, No. 12, 1269-1280, doi: 10.1016/j.jbusres.2009.01.001.

[5] Armbruster, H., Bikfalvi, A., Kinkel, S., Lay, G. (2008). Organizational innovation: The challenge of measuring nontechnical innovation in large-scale surveys, Technovation, Vol. 28, No. 10, 644-657.

[6] Camisón, C., Villar-López, A. (2011). Non-technical innovation: Organizational memory and learning capabilities as antecedent factors with effects on sustained competitive advantage, Industrial Marketing Management, Vol. 40, No. 8, 1294-1304, doi: 10.1016/j.indmarman.2011.10.001.

[7] Camisón, C., Villar-López, A. (2014). Organizational innovation as an enabler of technological innovation capabilities and firm performance, Journal of Business Research, Vol. 67, No. 1, 2891-2902, doi: 10.1016/i.jbusres. 2012.06.004.

[8] Keupp, M.M., Palmié, M., Gassmann, O. (2012). The strategic management of innovation: A systematic review and paths for future research, International Journal of Management Reviews, Vol. 14, No. 4, 367-390, doi: 10.1111/ j.1468-2370.2011.00321.x.

[9] Laforet, S. (2011). A framework of organisational innovation and outcomes in SMEs, International Journal of Entrepreneurial Behaviour \& Research, Vol. 17, No. 4, 380-408.

[10] Rosenbusch, N., Brinckmann, J., Bausch, A. (2011). Is innovation always beneficial? A meta-analysis of the relationship between innovation and performance in SMEs, Journal of Business Venturing, Vol. 26, No. 4, 441-547, doi: 10.1016/j.jbusvent.2009.12.002.

[11] Bradley, S.W., McMullen, J.S., Artz, K., Simiyu, E.M. (2012). Capital is not enough: Innovation in developing economies, Journal of Management Studies, Vol. 49, No. 4, 684-717, doi: 10.1111/i.1467-6486.2012.01043.x.

[12] Alegre, J., Chiva, R. (2008). Assessing the impact of organizational learning capability on product innovation performance: An empirical test, Tehnovation, Vol. 28, No. 6, 315-326, doi: 10.1016/j.technovation.2007.09.003.

[13] Armbruster, H., Kirner, E., Lay, G., Szwejczewski, M., Coriat, B., Leguehennec, C., Evangelista, R., Pianta, M., Cozza, C., Belak, Jernej; Belak, Janko; Duh, M. (2006). Patterns of organisational change in European industry (PORCH) Ways to strengthen the empirical basis of research and policy, Fraunhofer Institute for Systems and Innovation Research, Karlsruhe, European Commission, Directorate-General for Enterprise and Industry, Innovation Policy Unit.

[14] Prester, J., Bozac, M.G. (2012). Are innovative organizational concepts enough for fostering innovation?, International Journal of Innovation Management, Vol. 16, No. 1, 1-23, doi: 10.1142/S1363919611003404.

[15] Lam, A. (2005). Organizational innovation, In: Fagerberg, J., Mowery, D.C., Nelson, R.R. (eds.), The Oxford handbook of innovation, Oxford, Oxford University Press, UK, 115-147.

[16] Damanpour, F., Aravind, D. (2012). Managerial innovation: Conceptions, processes, and antecedents, Management and Organization Review, Vol. 8, No. 2, 423-454, doi: 10.1111/j.1740-8784.2011.00233.x.

[17] OECD/Eurostat (2005). Oslo manual: Guidelines for collecting and interpreting innovation data, $3^{\text {rd }}$ edition, The Measurement of Scientific and Technological Activities, OECD Publishing, Paris.

[18] Hong, S., Oxley, L., McCann, P. (2012). A survey of the innovation surveys, Journal of Economic Surveys, Vol. 26, No. 3, 420-444, doi: 10.1111/j.1467-6419.2012.00724.x.

[19] De Faria, P., Mendonca, J. (2011). Innovation strategy by firms: Do innovative firms grow more?, International Journal of Entrepreneurship and Small Business, Vol 12, No. 2, 173-184, doi: 10.1504/IJESB.2011.038535.

[20] Jiménez-Jiménez, D., Sanz-Valle, R. (2011). Innovation, organizational learning, and performance, Journal of Business Research, Vol. 64, No. 4, 408-417, doi: 10.1016/i.jbusres.2010.09.010.

[21] Laforet, S. (2013). Organizational innovation outcomes in SMEs: Effects of age, size, and sector, Journal of World Business, Vol. 48, No. 4, 490-502, doi: 10.1016/j.jwb.2012.09.005.

[22] Jin, Z., Hewitt-Dundas, N., Thompson, N.J. (2004). Innovativeness and performance: Evidence from manufacturing sectors, Journal of Strategic Marketing, Vol. 12, No. 4, 255-266, doi: 10.1080/0965254042000308075.

[23] Crossan, M.M., Apaydin, M. (2010). A multi-dimensional framework of organizational innovation: A systematic review of the literature, Journal of Management Studies, Vol. 47, No. 6, 1154-1191, doi: 10.1111/i.1467-6486. 2009.00880.x.

[24] Evangelista, R., Vezzani, A. (2010). The economic impact of technological and organizational innovations. A firmlevel analysis, Research Policy, Vol. 39, No. 10, 1253-1263, doi: 10.1016/j.respol.2010.08.004.

[25] Gumusluoğlu, L., Ilsev, A. (2009). Transformational leadership and organizational innovation: The roles of internal and external support for innovation, The Journal of Product Innovation Management, Vol. 26, No. 3, 264-277, doi: 10.1111/i.1540-5885.2009.00657.x.

[26] Gunday, G., Ulusoy, G., Kilic, K., Alpkan, L. (2011). Effects of innovation types on firm performance, International Journal of Production Economics, Vol. 133, No. 2, 662-676, doi: 10.1016/i.ijpe.2011.05.014.

[27] Lin, C.Y.Y., Chen, M.Y.C. (2007). Does innovation lead to performace? An empirical study of SMEs in Taiwan, Management Research News, Vol. 30, No. 2, 115-132, doi: 10.1108/01409170710722955.

[28] Belderbos, R., Carree, M., Lokshin, B. (2004). Cooperative R\&D and firm performance, Research Policy, Vol. 33, No. 10, 1477-1492, doi: 10.1016/j.respol.2004.07.003. 
[29] Kim, S.T., Hong, S.R., Kim, C.O. (2014). Product attribute design using an agent-based simulation of an artificial market, International Journal of Simulation Modelling, Vol. 13, No. 3, 288-299, doi: 10.2507/IJSIMM13(3)3.266.

[30] Kusar, J., Bradesko, L., Duhovnik, J., Starbek, M. (2008). Project management of product development, Strojniški vestnik - Journal of Mechanical Engineering, Vol. 54, No. 9, 588-606.

[31] Kaljun, J., Dolšak, B. (2012). Improving products' ergonomic value using intelligent decision support system, Strojniški vestnik - Journal of Mechanical Engineering, Vol. 58, No. 4, 271-280, doi: 10.5545/sv-jme.2011.193.

[32] Yu, G.D., Yang, Y., Zhao, X., Li, G. (2014). Multi-objective rescheduling model for product collaborative design considering disturbance, International Journal of Simulation Modelling, Vol. 13, No. 4, 472-484, doi: 10.2507/ IJSIMM13(4)CO17.

[33] Evangelista, R., Sandven, T., Sirilli, G., Smith, K. (1998). Measuring innovation in European industry, International Journal of the Economics of Business, Vol. 5, No. 3, 311-333, doi: 10.1080/13571519884413. 